\title{
THE STUDY OF CALCIUM HYDROXIDE STRUCTURE AND ITS PHYSICO-CHEMICAL AND ELECTROKINETIC PROPERTIES IN SUGAR PRODUCTION
}

\author{
Lidiia Vyerchenko ${ }^{1}$, Serhii Tkachenko ${ }^{1,}{ }^{凶}$, Tamila Sheiko ${ }^{1}$, \\ Tetiana Kos', Olha Dzhohan', Volodymyr Vasyliv ${ }^{2}$
}

https://doi.org/10.23939/chcht13.04.477

\begin{abstract}
This article discusses the influence of the methods of lime cream generation and its physicochemical properties on raw juice purification process. It offers some measures for the raw juice clarification process failure prevention that stem from the methods of lime cream preparation. The electrokinetic potential of the lime cream is studied and the structure of calcium hydroxide micelle is proposed.
\end{abstract}

Keywords: raw juice, lime cream, rheological properties, electrokinetic potential.

\section{Introduction}

Sugar production has used lime for the raw juice clarification for 210 years. Lime is used in the form of the lime cream, which represents water and lime suspension of hydrated lime. This provides the improvement of the lime unit hygiene, facilitates lime clarification and makes it convenient to dose. Consequently, during the raw juice clarification, non-sugars react with calcium hydroxide and therefore it is the main reagent providing raw juice clarification.

Further carbonization of calcium hydroxide into calcium carbonate provides additional reagent for raw juice clarification. Another part of non-sugars (mainly coloring compound) is removed on the surface of this reagent due to adsorption.

Nowadays it is widely accepted that raw juice clarification process and the clarified juices quality depend on methods of lime cream generation and its physicochemical properties [1]. It is shown that commercially produced lime cream represents hard phase

\footnotetext{
${ }^{1}$ Institute of Food Resources, National Academy of Agrarian Sciences of Ukraine,

4, A. Yevhena Sverstiuka St., 02002 Kyiv, Ukraine

${ }^{2}$ National University of Life and Environment Sciences of Ukraine,

15, Heroiv Oborony St., 03041 Kyiv, Ukraine

sergi-tkachenko@ukr.net

(C) Vyerchenko L., Tkachenko S., Sheiko T., Kos T., Dzhohan O., Vasyliv V., 2019
}

of calcium hydroxide with specific surface ranging from 3.5 to $5.8 \mathrm{~m}^{2} / \mathrm{g}$, that is due to the dimension of calcium hydroxide crystals varying from 0.2 to $15 \mu \mathrm{m}$. This range of dimensions argues for the lime cream (specifically lime cream used in the sugar production) being a suspension rather than colloid system [2] as it was postulated by some researches. Distribution diagram obtained for the particles dimensions of the lime cream hard phase $\left(\mathrm{Ca}(\mathrm{OH})_{2}\right)$ [3] shows that in the most samples $50-60 \%$ of the total hard phase is made of particles of middle size $(10-14 \mu \mathrm{m}), 10$ $30 \%$ - of particles of more than $15 \mu \mathrm{m}$ in size and 20 $30 \%-$ of particles of small fraction $(0.2-1 \mu \mathrm{m})$. Thus, lime cream is a water-lime polydisperse suspension. Burning of fine-crystalline limestones at a plant results in the increase percentage of small fraction of the hard phase. This leads to emergence of fine-crystalline suspension with hard phase capable of binding a large amount of water. It results in the reduction of the level of free water serving a layer, which facilitates lime cream flow, and thus the suspension loses its rheological properties. Subsequently the lime cream suspension loses its fluidity, which complicates its clarification and dosing. Visually that kind of lime cream seems to be very viscous. Nevertheless, measuring of its density with pycnometer (not densimeter) according to the recommendations of the "Chemical-technical control and sugar production accounting rules" gives the value of about $1.13-1.15 \mathrm{~g} / \mathrm{cm}^{3}$. In such cases, in order to increase fluidity, facilitate clarification and transfer through a pipeline, lime cream is diluted with water, which further decreases its density. When this occurs, machine of the juice purification house is supplied with lime cream with high content of water, which dilutes juice and increases evaporator unit loading.

\section{Experimental}

For the study, only freshly prepared samples of aqueous suspension of calcium hydroxide with $\mathrm{CaO}$ concentrations of 7.0 and $18.0 \%$ were used. 
On-line determination of electrokinetic potential of calcium hydroxide micelles was conducted with the use of "suspension effect" (SE) method, basing on the $\mathrm{pH}$ measurement of suspension and suspension filtrate under study $[4,5]$. Suspension or colloid-concentrating effect emerges, providing the suspension is charged and is conditioned by the ionization of the dispersed particles and adsorption on their surface of ions present in the solution. In this case $\mathrm{pH}$ of suspension and filtrate will differ. It is also known that the sign (positive or negative) of SE corresponds to the charge sign of dispersed phase. Earlier it was shown [4] that electrokinetic potential of suspension makes $100 \mathrm{SE}$. The approximate value of the electrokinetic potential $(\mathrm{mV})$ is calculated as the difference between $\mathrm{pH}$ of suspension and $\mathrm{pH}$ of suspension filtrate multiplied by 100 .

The sign of electrokinetic potential was determined by electrophoresis with the use of the Berton unit and direct-current power supply.

The high-precision measurement of electrokinetic potential of hard phase particles in water-lime cream sus- pension was performed by combination of electrophoretic method and dynamic light scattering method with the use of Zetasizer Nano ZS (Malvern Instrument Ltd., UK). $4 \mathrm{~mW} / 633 \mathrm{~nm}$ HeNe laser served as a light source. The measurements were conducted at the temperature of $298 \pm 0.1 \mathrm{~K}$ with minimum of 3 replicates. The statistical processing of data was accomplished through the Zetasizer Software version 6.20. Sample preparation was done in accordance with the procedure description in [6]. Sample stability was estimated relative to the reference standard [7].

\section{Results and Discussion}

The Table summarizes the data on excess water entering juice clarification unit with diluted lime cream as well as the data on fuel overconsumption due to its evaporation. These values are calculated for sugar mill with processing capacity of 3.000 tons of beets per day and the rate of lime cream consumption for diffusion juice clarification of $2.5 \%$ by weight of beets.

\section{The effect of reduction of lime cream density on the flow rate of water evaporated from juice} and overconsumption of fuel

\begin{tabular}{|c|c|c|c|c|}
\hline $\begin{array}{c}\text { Initial lime cream } \\
\text { density at the } \\
\text { beginning of raw juice } \\
\text { liming, } \mathrm{g} / \mathrm{cm}^{3}\end{array}$ & $\begin{array}{c}\text { Flow rate of water } \\
\text { delivered with lime } \\
\text { cream to evaporator } \\
\text { unit, ton/24h }\end{array}$ & $\begin{array}{c}\text { Flow rate of secondary } \\
\text { steam spent for water } \\
\text { evaporation, ton/24h }\end{array}$ & $\begin{array}{c}\text { Flow rate of fuel } \\
\text { equivalent spent for } \\
\text { secondary steam } \\
\text { production, ton/24h }\end{array}$ & $\begin{array}{c}\text { Flow rate of natural } \\
\text { gas spent for } \\
\text { secondary steam } \\
\text { production, } \\
1000 \mathrm{~m}^{3} / 24 \mathrm{~h}\end{array}$ \\
\hline 1.20 & 254 & 101.6 & 10.16 & 8.91 \\
\hline 1.18 & 285 & 114.0 & 11.40 & 10.0 \\
\hline 1.16 & 324 & 129.6 & 12.96 & 11.37 \\
\hline 1.14 & 375 & 150.0 & 15.00 & 13.16 \\
\hline 1.12 & 438 & 175.2 & 17.52 & 15.37 \\
\hline
\end{tabular}

The above calculations are based on the estimation that 1 ton of secondary steam provides evaporation of 2.5 tons of water; 1 ton of secondary steam is generated via consumption of 0.1 ton of fuel equivalent and conversion factor for fuel equivalent relatively to $1000 \mathrm{~m}^{3}$ of natural gas comprises 1.14. The usage of diluted lime cream induces the growth of lime consumption that goes for treatment of the increased level of juice. It is apparent from the foregoing that seeming density of lime cream may be deceptive and therefore it is recommended that the density should be measured with pycnometer and not densimeter. According to our findings, unfit rheological properties of lime cream should be improved with application of more severe mode of limestone burning [8] and not dilution with water. The mode of limestone burning should be as follows: flow rate of anthracite should comprise not less than $7.5 \%$ of furnace charge, given that specific output of $\mathrm{CaO}$ is less than 9 tons from
$1 \mathrm{~m}^{2}$ of kiln cross section area per $24 \mathrm{~h}$ ( 9 tons $\mathrm{CaO} \mathrm{m} / 24 \mathrm{~h}$ ). Application of this mode results in the increase of temperature in the burning zone up to $1473 \mathrm{~K}$. This temperature induces the process of thermal dissociation of calcium carbonate in the burning zone, as well as lime agglomeration and recrystallization, i.e. thickening of lime lumps and growth of big crystals at the cost of small crystals [9]. The total amount of small crystals significantly decreases and, therefore, slaking results in lime cream with suitable rheological properties [10].

Adjustment of burning mode and crystalline structure of lime will allow for the usage of washings for lime slaking. The underlying mechanism is that sucrose facilitates the disintegration of the hard phase, which, on the other hand, may cause the slump loss of lime cream. However, this problem can be solved by using the moderate mode of burning. There are some literature data [11] attesting that application of sucrose may inhibit the 
lime slaking process. However, these data are not applicable for sugar production as they were obtained for the specifications of concrete manufacturing process, for which another type of lime is used, in particular, semiactive lime, burned at the temperature of $1623-1773 \mathrm{~K}$. For the needs of sugar production only active lime is used, burned at the temperature of 1373-1523 K, which prevents the inhibiting influence of sucrose. Besides, there exists the best industrial practice of lime slaking with washouts of pressure filters containing not less than $2 \%$ of dry matter. However, the degradation of sucrose in case of slaking of lime with sugar-containing solutions is not studied until now. Lime cream preparation at the sugarhouse is conducted within the temperature range of 313$373 \mathrm{~K}$ at $\mathrm{pH}_{20}=12.5$ and continues for $2-2.5 \mathrm{~h}$. Under production conditions the amount of degraded sucrose depends on the value of $\mathrm{pH}$, temperature and the exposition time, thus the slaking of lime with sugarcontaining solutions may result in sucrose degradation. According to the existing literature data, obtained by different authors using different methods, sucrose degradation level varies from 0.5 to $15.4 \%$, depending on the amount of sucrose applied [12]. However, it should be emphasized that determining small amounts of sucrose with polarimetry, used for all the mentioned studies, is characterized by big errors. In order to determine unprovisioned manufacturing losses of sugar, such as the overall amount of degraded sucrose, generated as a result of lime slaking, and the amount of degraded sucrose at the regions of lime separation, we have used the up-to-date method, based on calculation of invert sugar/acid radical ratio. The model solutions used for this investigation were solutions of refined granulated sugar and process washings with sugar concentration of $2.85-10.0 \mathrm{wt} \%$. It was shown that the total amount of sucrose degrading at the lime department machine comprises approximately $5.0 \mathrm{wt} \%$ of sugar used, which corresponds to $0.02 \mathrm{wt} \%$ of beetroot mass. A great part of the sucrose degraded in the process of the lime slaking $(67 \%)$ is due to the limeslaking machine and corresponds to $0.013 \%$ of the beetroot mass. In view of this, the amount of degraded sucrose resulting from lime slaking with sucrosecontaining solutions remains within the range of values referred to as unprovisioned manufacturing losses of sugar.

Now slaking of lime with washouts becomes more and more relevant due to modernization of the filtering equipment of the juice purification houses, and specifically due to implementation of pressure filters of new design and the new data showing the high activating potency of sucrose concerning lime cream [12]. The latter promotes the overall juice purification level and therefore boosts the sugar yield.
Taking into account the fact that lime cream represents water and lime suspension, it should share all the properties common for dispersed system. These are primarily surface phenomena, including the electrical double layer (EDL) surrounding each solid particle in the system [2].

Calcium hydroxide is relatively insoluble in water. According to [12] at $298 \mathrm{~K}$ the rate of $\mathrm{CaO}$ solubility in water is about $0.176 \mathrm{~g} / 100 \mathrm{~cm}^{3}$, and in $11 \%$ solution of sucrose $-1.55 \mathrm{~g} / 100 \mathrm{~cm}^{3}$. In solution calcium hydroxide dissociates in two stages:

$$
\begin{aligned}
& \text { I) } \mathrm{Ca}(\mathrm{OH})_{2} \rightleftarrows \mathrm{CaOH}^{+}+\mathrm{OH}^{-} ; K_{d}=1.00 \\
& \text { II) } \mathrm{CaOH}^{+} \rightleftarrows \mathrm{Ca}^{2+}+\mathrm{OH}^{-} ; K_{d}=0.03
\end{aligned}
$$

As it can be seen from Eq. (1), at the first stage $100 \%$ of $\mathrm{Ca}(\mathrm{OH})_{2}$ dissociate, while at the second stage only $3 \%$ [13], whereas according to other authors [13] about $16.5 \%$ of $\mathrm{CaOH}^{+}$dissociates. Even such a high dissociation level provides only a low level of $\mathrm{Ca}^{2+}$ concentration in the solution. The most widespread ions in the lime milk solution are $\mathrm{CaOH}^{+}$and $\mathrm{OH}^{-}$, which is due to high $\mathrm{pH}_{20}$ value of lime milk suspension, comprising 12/53. It was proposed [14] to generate $\mathrm{Ca}(\mathrm{OH})_{2}$ micelles from its dispersed solution - lime cream (3). According to Eq. (3) $\mathrm{Ca}(\mathrm{OH})_{2}$ micelle includes two ions $-\mathrm{OH}^{-}$and $\mathrm{H}^{+}$.

$$
\left\{\mathrm{m}\left[\mathrm{Ca}(\mathrm{OH})_{2}\right] \mathrm{nOH}^{-}(\mathrm{n}-\mathrm{x}) \mathrm{H}^{+}\right\}^{-} \mathrm{xH}^{+}
$$

In our opinion, this model of calcium hydroxide micelle in lime milk is not true, as solid phase of calcium hydroxide represents a crystalline substance, which consists of $\mathrm{Ca}^{2+}$ and $\mathrm{OH}^{-}$[15].

According to the Fajans-Paneth precipitation and adsorption rule [2], only those ions which compose crystal lattice and are present in dispersed medium in excess are capable of adsorption on the hard particles and can play the role of potential determining ions. Lime cream contains four types of ions $\left(\mathrm{Ca}^{2+} \mathrm{CaOH}^{+}, \mathrm{OH}^{-} \mathrm{Ta} \mathrm{H}^{+}\right)$but only two of them are in excess $-\mathrm{CaOH}^{+}$and $\mathrm{OH}^{-}$. The excess of $\mathrm{OH}^{-}$is caused by the high $\mathrm{pH}$ value of the dispersed medium, while the excess of $\mathrm{CaOH}^{+}$is due to the low level of calcium hydroxide dissociation. Provided the high alkalinity of the calcium hydroxide suspension, only hydroxyl ion can play the role of potential determining ion or co-ion, as it is reflected in Eq. (3), whereas counter-ions can be represented only by calcium hydroxide ions as the level of $\mathrm{H}^{+}$at the high values of $\mathrm{pH}$ is too low to perform this function.

With these considerations micelles of calcium hydroxide in its saturated solution should have the structure represented in Fig. 1. 


\section{Micelle electroneutral

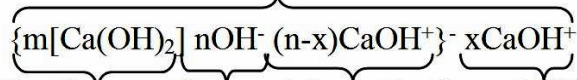 \\ Micelle core Coion Adsorptivellayer Diffuselayer \\ Micelleparticle negativelycharged}

Fig. 1. Calcium hydroxide micelle in its saturated solution

As can be seen from Fig. 1, the surface charge of the solid $\mathrm{Ca}(\mathrm{OH})_{2}$ with $\mathrm{OH}^{-}$playing the role of the potential determining ion is compensated with the sum of adsorption and diffusion layer charges, which makes micelles overall electroneutral. However, the total negative charge of the co-ions (potential determining ion) exceeds the total positive charge of counter-ions of the adsorbed layer, so that overall the calcium hydroxide micelle is negatively charged. As for the positively charged diffuse layer, comprising mainly calcium hydroxide ions, it is poorly attracted by the micelle, because the interaction energy of these ions with the nucleus is rather small - only several $\mathrm{kcal} / \mathrm{mol}$ [2]. For this reason, calcium hydroxide ions are constantly "drifting", exchanging with the ions of the same sign present in the solution. It should therefore be expected that the electrokinetic potential of a calcium hydroxide aqueous suspension, which is caused mainly by the drift of the diffuse layer ions, must be positive. This is verified by the fundamental research [16], demonstrating that electrokinetic potential of the lime cream is positive and comprises not more than $+20 \mathrm{mV}$. In addition, this value is independent of impurities present in solution and ion concentration in the surrounding solution [16].

We have measured the approximate value of the electrokinetic potential of calcium hydroxide suspension using the method proposed in [4], which is based on measuring the $\mathrm{pH}$ of the suspension and its filtrate with subsequent calculation of the so-called "suspension effect". Experiments were conducted using freshly prepared samples of calcium hydroxide aqueous suspension with $\mathrm{CaO}$ concentration of 7.0 and $18.0 \%$, and the value of electrokinetic potential was 13.0 and $12.0 \mathrm{mV}$, respectively. This confirms the results of studies [16] supporting the independence of electrokinetic potential from the concentration of ions in solution. Also, by electrophoresis we were able to confirm a positive sign of the charge of diffuse layer of calcium hydroxide micelle, as indicated by the increased concentration of solids at the negatively charged electrode (Fig. 2).

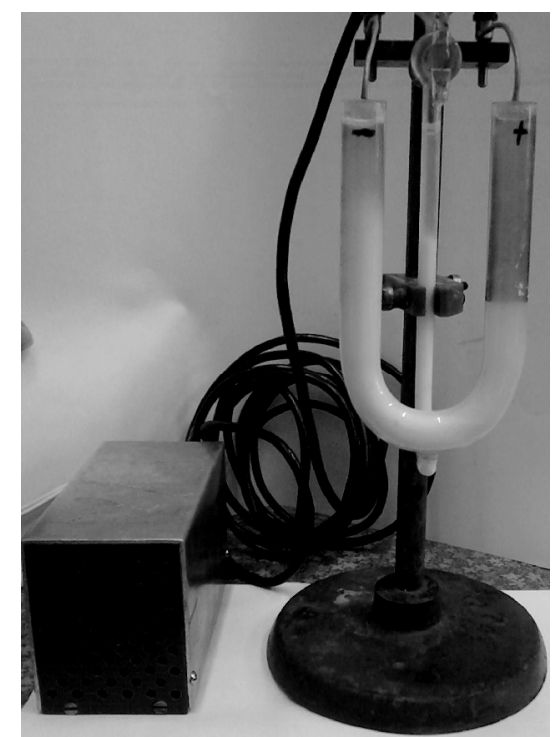

Fig. 2. Electrophoresis of $\mathrm{Ca}(\mathrm{OH})_{2}$ suspension with Burton's apparatus

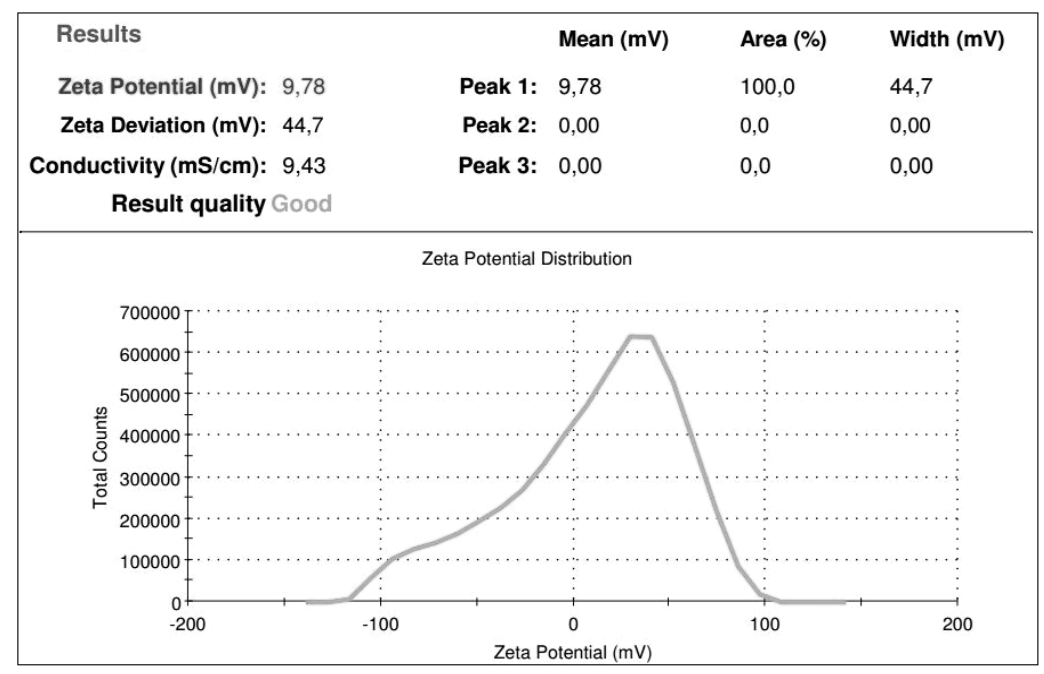

Fig. 3. Distribution of electrokinetic potential in water suspension of calcium hydroxide 
For a more accurate measurement of electrokinetic potential of calcium hydroxide aqueous suspension we used analyzer Zetasizer Nano ZS. Thus, the value of electrokinetic potential was measured to be $+9.78 \mathrm{mV}$ (Fig. 3).

According to the previous researches [7], the value of electrokinetic potential obtained in our experiments indicates that the dispersed system is in a state of initial instability, characterized by very slight rate of subsidence and stratification.

\section{Conclusions}

The fact that counter-ions of calcium hydroxide micelle are represented by ions of calcium hydroxide rather than $\mathrm{Ca}^{2+}$ cations negatively affects the cleaning process. In accordance with the Schulze-Hardy rule, these are counter-ions of micelles that induce coagulation of colloidal dispersion matter and macromolecular compounds of raw juice. Moreover, its coagulating ability increases proportionally to the level of charge. This means that the protein and pectin compounds of raw juice will precipitate in the form of calcium hydroxide complexes and not $\mathrm{Ca}^{2+}$ complexes. Calcium hydroxide complexes with proteins and pectins are easily peptized in high alkaline conditions and therefore partly go into solution during the main liming process, thus reducing the coagulation effect of the preliminary liming and compromising the quality of juice. The latter urges sugar production technologists to look for additional reagents that would contain polyvalent cations with high complexing ability and justifies the need for discarding of preliminary liming precipitation before the main refinery defecation.

Thus, in sugar production the obtaining of lime cream with acceptable density and rheological properties is possible only conditioned by adjustment of the limestone burning mode and crystalline structure of lime, as well as using washings for lime slaking. Compromising of raw juice quality in high alkaline conditions during the main liming process is caused by physical and chemical structure of calcium hydroxide micelles, which provide the solution with calcium hydroxide ions, forming complexes with proteins and pectins, which are unstable to peptization under conditions of high alkalinity. This is another reason for discarding of pre-defecation precipitation before the main liming.

\section{Acknowledgements}

The authors would like to thank Mr. Andrii Marynin (Problem Research Laboratory, National University of Food Technologies, Kyiv, Ukraine) for technical support in determining the electrokinetic potential of lime cream particles on the Zetasizer Nano ZS analyzer.

\section{References}

[1] Gusaruk T., Vyerchenko L., Homichak L. et al.: Tsukor Ukrainy, 2007, 2, 28.

[2] Shaw D.: Introduction to Colloid and Surface Chemistry, $4^{\text {th }}$ edn. Butterworth-Heinemann, Oxford 2013.

[3] Vyerchenko L., Homichak L., Gusaruk T. et al.: Tsukor Ukrayiny, 2005, 1-2, 31.

[4] Susie X., Cheng K., Kurtz L. et al.: Particul. Sci. Technol., 1989, 7, 139. https://doi.org/10.1080/02726358908906533

[5] Ohshima H.: Theory of Colloid and Interfacial Electric Phenomena, $1^{\text {st }}$ edn. Academic Press, Oxford 2006.

[6] Zetasizer Nano User's manual. Malvern Instruments Ltd., Malvern, United Kingdom 2009.

[7] ASTM Standard D4187-82 (1985) Test Methods For Zeta Potential Of Colloids In Water And Waste Water, American Society for Testing and Materials, West Conshohocken, Pennsylvania 1985. [8] Yarchuk M., Kalinichenko M., Chupahina V.: Pravila vedennya tehnologichnogo protsesu virobnitstva tsukru $\mathrm{z}$ tsukrovih buryakiv. Pravila ustalenoyi praktiki. Tsukor Ukrayiny, Kiev, 2007.

[9] Fennell P., Anthony B.: Calcium and Chemical Looping Technology for Power Generation and Carbon Dioxide $\left(\mathrm{CO}_{2}\right)$ Capture. Woodhead Publishing, Oxford 2015.

[10] Gusaruk T., Verchenko L., Homichak L.: Pat. UA 20060454, Publ. Oct. 16, 2006.

[11] Aitsin P.-C., Flatt R.: Science and Technology of Concrete Admixtures, $1^{\text {st }}$ edn. Woodhead Publishing, Oxford 2015.

[12] Tkachenko S., Sheiko T., Dzhohan O. et al.: Tsukor Ukrainy, 2018, 2(144), 28.

[13] Lambert I., Clever H.: Alkaline Earth Hydroxides in Water and Aqueous Solutions, $1^{\text {st }}$ edn. Pergamon, Oxford 1992.

[14] Savostin A., Shurai P.: Sahar, 2008, 5, 64.

[15] Hewlett P.: Lea's Chemistry of Cement and Concrete, 4 edn. Butterworth-Heinemann, Oxford 2003.

[16] Wittneben U.: Zement-Kalk-Gips, 1980, 33, 526.

Received: April 02, 2018 / Revised: May 25, 2018 / Accepted: September 12, 2018

\section{ДОСЛІДЖЕННЯ СТРУКТУРИ, ФІЗИКО- ХІМІЧНИХ І ЕЛЕКТРОКІНЕТИЧНИХ ВЛАСТИВОСТЕЙ ГІДРОКСИДУ КАЛЬЦЮЮ У ЦУКРОВОМУ ВИРОБНИЦТВІ}

Анотація. В статті наведено деякі основні положення впливу методів одержання вапняного молока та його фізикохімічної природи на технологічний прочес очищення дифузійного соку. Запропоновані засоби запобігання порушень технологічного режиму очищення дифузійного соку, які спричинені методами приготування вапняного молока. Досліджено електрокінетичний потенціал вапняного молока та запропоновано структуру міцели гідроксиду кальцію вапняного молока.

Ключові слова: дифузійний сік, вапняне молоко, реологічні властивості, електрокінетичний потенціал. 